\title{
Echinocandins for management of invasive candidiasis in patients with liver disease and liver transplantation
}

\section{Siang Fei Yeoh' \\ Tae Jin Lee ${ }^{2}$ \\ Ka Lip Chew ${ }^{3}$ \\ Stephen $\operatorname{Lin}^{4}$ \\ Dennis Yeo ${ }^{5}$ \\ Sajita Setia ${ }^{5}$}

'Department of Pharmacy, National University Health System, Singapore, Singapore; ${ }^{2}$ Department of Pharmacy, National University of Singapore, Singapore, Singapore; ${ }^{3}$ Department of Laboratory Medicine, National University Hospital, Singapore, Singapore; ${ }^{4} \mathrm{Global}$ Medical Affairs, Asia-Pacific region, Pfizer, Hong Kong, People's Republic of China; ${ }^{5}$ Medical Affairs, Pfizer Pte. Ltd., Singapore, Singapore
Correspondence: Sajita Setia Medical Affairs, Pfizer Pte. Ltd., 80 Pasir Panjang Road, \#16-81/82, Mapletree Business City, Singapore 117372 ,

Singapore

Tel +6564038754

Fax +6567224188

Email sajita.setia@pfizer.com
This article was published in the following Dove Press journal: Infection and Drug Resistance

\begin{abstract}
Candida species remains one of the most important causes of opportunistic infections worldwide. Invasive candidiasis (IC) is associated with considerable morbidity and mortality in liver disease (LD) patients if not treated promptly. Echinocandins are often recommended as a first-line empirical treatment for managing IC and can especially play a critical role in managing IC in LD patients. However, advanced LD patients are often immunocompromised and critically ill. Hence altered pharmacokinetics, drug interactions as well as tolerance issues of antifungal treatments are a concern in these patients. This comprehensive review examines the epidemiology, risk factors and diagnosis of IC in patients with LD and evaluates differences between three available echinocandins for treating this group of patients.

Keywords: anidulafungin, caspofungin, candidemia, micafungin
\end{abstract}

\section{Introduction}

Advanced liver disease (LD) is characterized by post-inflammatory fibrosis and retardation of liver structure and function. Advanced LD patients generally present with ascites and exaggerated fibrinolysis, while pain, fatigue, abdominal pain are also some common secondary symptoms. ${ }^{1,2}$ End-stage liver disease (ESLD) refers to advanced LD along with liver failure and decompensated cirrhosis. ${ }^{1}$ Advanced LD patients generally have low host immunity and comorbidities such as renal impairment and diabetes, and are highly vulnerable to opportunistic infections, mainly invasive fungal infections (IFIs). ${ }^{3,4}$ Advanced LD leads to persistent systemic inflammation, which damages the cellular structure of the reticuloendothelial system, impairs the innate immune response and ultimately renders hepatic patients immunodeficient. ${ }^{5,6}$

Increased numbers of dysfunctional monocytes and macrophages, the regulators of MER receptor tyrosine kinase, which are known to suppress the innate immune system, have been observed in patients with acute-on-chronic liver failure. ${ }^{7}$ Increase in the number of these regulators is linked with severity of inflammation and disease prognosis. ${ }^{7}$ In severe alcoholic hepatitis ( $\mathrm{sAH}$ ), there is higher immunosuppression compared to cirrhosis, which also correlates to increased incidence of infection. This is due to the enhanced immunosuppressive profile of $\mathrm{T}$ lymphocytes resulting from higher chronic lipopolysaccharide exposure observed in sAH (Figure 1). ${ }^{8,9}$ Another reason for increased risk of both opportunistic fungal infections and IFIs in sAH patients is due to prolonged steroid use, which is the first-line therapy to improve the patient outcomes in this group of patients. ${ }^{8,10,11}$ Similarly, other iatrogenic 


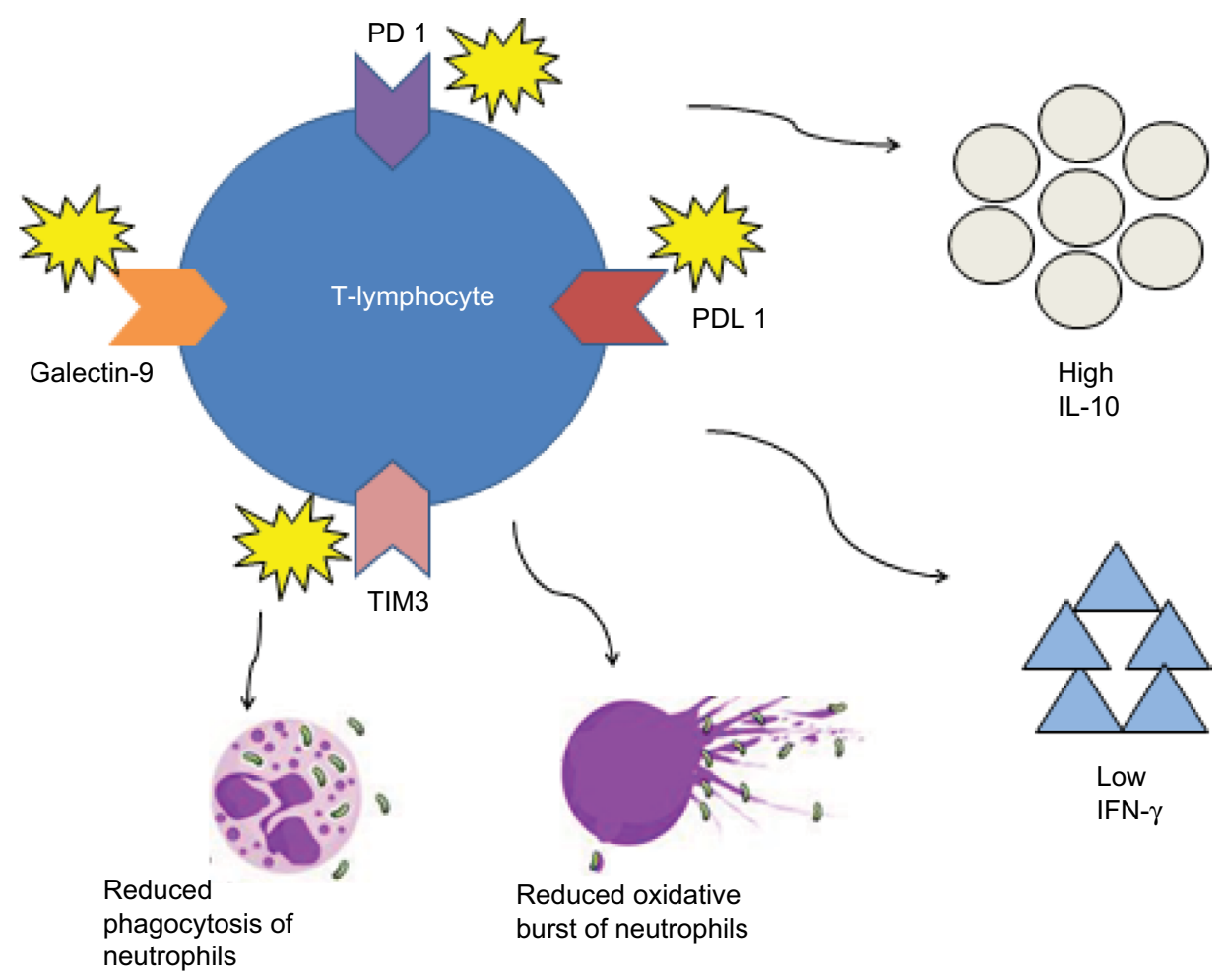

Figure I Pathophysiology for immunosuppression in severe alcoholic hepatitis.

Notes: Higher chronic lipopolysaccharide exposure leads to overexpression of inhibitory receptors (PD I, PDL I, TIM3 and galectin-9) on T lymphocytes resulting in higher IL-10 and lower IFN- $\gamma$ production as well as reduced neutrophil antimicrobial activities (e.g., phagocytosis and oxidative burst).

Abbreviations: IFN- $\gamma$, interferon- $\gamma$; IL- I0, interleukin- I0; PD I, programmed cell death protein I; PDL I, programmed death ligand I; TIM3, T-cell immunoglobulin mucin-3.

factors, such as immunosuppressive therapy, are additional risk factors for IFIs in liver transplantation patients, especially those with primary graft failure (repeated surgery/ re-transplantation). ${ }^{12-14}$

Patients with LD in intensive care units (ICUs) are more susceptible to opportunistic fungal infections including invasive candidiasis (IC), mainly aggravated by nosocomial infection factors such as colonization of indwelling catheters by Candida spp. ${ }^{15}$ According to a 1-day, prospective, point prevalence multi-country study, Candida spp. were the third most common pathogen in ICUs, after Staphylococcus aureus and Pseudomonas spp., with an infection rate of $17 \% .{ }^{16}$ Candidemia is the fourth most common blood infection in nosocomial settings, especially in ICU settings. ${ }^{17}$ It is important to highlight that IC includes not only candidemia, but also deep-seated tissue candidiasis. The latter can also potentially lead to secondary candidemia through hematogenous dissemination or inoculation in sterile sites. ${ }^{18}$

Fungal infections are an emerging problem in cirrhotic patients and are usually fatal. ${ }^{19}$ Candida spp. infection accounts for $10 \%$ of total IFIs in cirrhotic patients. ${ }^{20}$ Although IC may be a rare complication in hepatic patients, there is a high mortality risk if diagnosis and treatment are delayed. ${ }^{20}$ Timely initiation of antifungal therapy is found to lower mortality rates in IC patients. ${ }^{21}$ Table 1 lists the major risk factors for development of IC in patients with LD.

Both Infectious Diseases Society of America (IDSA) and European Society of Clinical Microbiology and Infectious Diseases (ESCMID) guidelines recommend echinocandins as the first-line therapy for the initial management of IC (suspected or proven) using a stepdown approach..$^{22,23}$ While IDSA guidelines recommend de-escalation for fluconazole-susceptible strains when the patient becomes stable and ESCMID guidelines recommend de-escalation after 10 days of intravenous treatment, de-escalation to fluconazole is probably started much earlier than recommended in clinical practice as shown in the AmarCAND 2 trial. $^{24}$

Though these international guidelines do not differentiate amongst the three available echinocandins, there are 
Table I Major risk factors for invasive candidiasis in liver disease

\begin{aligned} \hline Risk factors & - Prolonged ICU admission \\ & - Parenteral nutrition \\ & - Indwelling catheters \\ & - Anastomotic leakage after laparotomy \\ - Recent antibiotic therapy and anti-fungal prophylaxis & for liver transplant recipients \\ - Internal prosthetic devices & - immunosuppression therapy (e.g., corticosteroids) \end{aligned}

Note: Data collated from Bassetti et al, ${ }^{28}$ Thursz et al ${ }^{10}$ and Vergis et al. ${ }^{139}$

Abbreviation: ICU, intensive care unit.

major differences between them largely related to the route of metabolism, half-life and safety. These are important in selecting appropriate agents in patients with LD. In this review, we have examined the epidemiology, risk factors and diagnosis of IC in patients with LD as well as in patients with liver transplantation. We have also studied the differences between three available echinocandins for treating this group of patients.

\section{Clinical presentation of invasive candidiasis}

Clinical presentations of IC in LD patients can be similar to bacterial infections. ${ }^{25}$ However, these patients may or may not present with associated bacterial infection and rather manifest as unimpeded fever after treatment with antibiotics, septic shock, leukocytosis as well as renal failure. ${ }^{26}$ In addition, it is difficult to differentiate spontaneous fungal peritonitis (SFP) from spontaneous bacterial peritonitis (SBP) based on ascitic fluid analysis alone. ${ }^{19}$ Therefore, clinicians should have a high index of suspicion and risk factor analysis is highly relevant in this context.

Candidemia is 10 times more common among ESLD patients compared to other LD patients (both cirrhotic and non-cirrhotic). ${ }^{27}$ Post-liver transplantation and cirrhotic patients generally present with candidemia ( $>50 \%)$. However, intraabdominal candidiasis (IAC) which includes peritonitis and abdominal abscesses is also commonly reported (40\%). ${ }^{19,28}$ ICU admission and mortality are found to be higher in liver transplant recipients (LTRs) with candidemia compared to those with abdominal candidiasis. ${ }^{29}$ More than one species of Candida spp. is frequently observed in patients presenting with abdominal candidiasis. ${ }^{28,30}$

Recent evidence suggests that the occurrence of SFP due to Candida spp. among critically ill patients with decompensated ESLD is comparable to SBP (10\% and $14 \%$ respectively), which could mean that SFP may not be as rare a complication in LD patients as that described in previous studies. ${ }^{31}$ Also, SFP in patients with cirrhosis is associated with worse outcomes, specifically severe sepsis/ septic shock ( $87.5 \%$ vs. $42.8 \% ; P=0.0023)$, admission in the gastroenterology ICU $(87.5 \%$ vs. $24.4 \% ; P=0.001)$ and higher overall (62.5 vs. $31.9 \% ; P=0.039)$ or 30 -day mortality ( 50.0 vs. $24.4 \%$; $P=0.034$ ), compared to SBP. ${ }^{32}$ Ascitic fluid lactate dehydrogenase, blood leukocyte count and urea nitrogen, invasive procedures and longer admission time are all independent risk factors for SFP as compared with patients without any infection. ${ }^{32}$

\section{Epidemiological characteristics of Candida spp. in liver disease patients}

Until recently, the most common isolated species during nosocomial IC was $C$. albicans; however, with changing epidemiology depending on geographical location, non- $C$. albicans has emerged as the predominant species in many countries. ${ }^{33}$ C. glabrata is recognized as the most common cause of candidemia in the USA and Europe. ${ }^{34,35}$ However, in Asian countries such as India and Singapore, the proportion of $C$. tropicalis was found to be one of the highest non- $C$. albicans in ICU settings, even outweighing the proportion of C. albicans. ${ }^{36,37}$

Candida spp. trends in LD patients relate to the epidemiological data of Asian countries. Although C. albicans infections are still a majority of Candida infection among LD patients, there has been increasing prevalence of non-albicans isolates. ${ }^{38}$ However, the proportion of $C$. parapsilosis appears to be higher in LTRs (Table 2). This pattern seems similar to patients with neutropenia where the second most isolated species is C. parapsilosis. ${ }^{39}$ Central venous lines and the use of parenteral nutrition are also more likely to be associated with $C$. parapsilosis compared to other fungal species. ${ }^{40}$ Increasing prevalence of infection by non-albicans spp., especially fluconazole-resistant C. parapsilosis among post-liver transplant patients is probably also due to long-standing adoption of antifungal prophylaxis among these patients and coincides with the history of temporal trend of prevalent use of fluconazole in mid- and late-1990s. ${ }^{41-43}$ Table 2 summarizes the common Candida spp. responsible for IC in LD and liver transplantation patients. 
Table 2 Common Candida spp. responsible for IC in liver disease and liver transplantation patients

\begin{tabular}{|c|c|c|}
\hline Study & Patient characteristics & $\begin{array}{l}\text { Common Candida } \\
\text { spp. types }\end{array}$ \\
\hline $\begin{array}{l}\text { Zicker } \\
\text { et } \text { al }^{140}\end{array}$ & $\begin{array}{l}\text { Post-liver transplant patients } \\
\text { with candidemia }(n=40) \text { from } \\
\text { Brazil }\end{array}$ & $\begin{array}{l}\text { C. albicans: } 20 \% \\
\text { C. glabrata: } 15 \% \\
\text { C. parapsilosis: } 18 \%\end{array}$ \\
\hline $\begin{array}{l}\text { Sganga } \\
\text { et } \mathrm{al}^{141}\end{array}$ & $\begin{array}{l}\text { Post-liver transplantation } \\
\text { patients with proven } \\
\text { candidemia }(n=26) \text { from Italy }\end{array}$ & $\begin{array}{l}\text { C. albicans: } 58 \% \\
\text { C. parapsilosis: } 19.2 \% \\
\text { C. glabrata: } 15.4 \%\end{array}$ \\
\hline $\begin{array}{l}\text { Bassetti } \\
\text { et } \mathrm{al}^{30}\end{array}$ & $\begin{array}{l}\text { Cirrhotic patients with } \\
\text { candidemia and IAC }(n=24 I) \\
\text { from Europe }\end{array}$ & $\begin{array}{l}\text { C. albicans: } 54.4 \% \\
\text { C. glabrata: } 14.5 \% \\
\text { C. parapsilosis: } 14.1 \%\end{array}$ \\
\hline $\begin{array}{l}\text { Bassetti } \\
\text { et } \mathrm{al}^{28}\end{array}$ & $\begin{array}{l}\text { Liver transplant recipients } \\
\text { with candidemia }(n=42) \text { from } \\
\text { Europe and Brazil }\end{array}$ & $\begin{array}{l}\text { C. albicans: } 59.5 \% \\
\text { C. parapsilosis: } 7.1 \% \\
\text { C. glabrata: } 4.8 \%\end{array}$ \\
\hline $\begin{array}{l}\text { Alexopoulou } \\
\text { zet al }{ }^{19}\end{array}$ & $\begin{array}{l}\text { Spontaneous fungal peritonitis } \\
\text { patients with positive cultures } \\
\text { obtained from ascetic fluid } \\
(n=126) \text { in Greece }\end{array}$ & $\begin{array}{l}\text { C. albicans: } 58 \% \\
\text { C. parapsilosis: I I\% } \\
\text { C. spp.: II\% }\end{array}$ \\
\hline $\begin{array}{l}\text { Lahmer } \\
\text { et } \mathrm{al}^{31}\end{array}$ & $\begin{array}{l}\text { Spontaneous fungal peritonitis } \\
\text { among critically ill patients with } \\
\text { liver cirrhosis }(n=205) \text { from } \\
\text { Germany }\end{array}$ & $\begin{array}{l}\text { C. albicans: } 60 \% \\
\text { C. glabrata: } 13 \% \\
\text { C. krusei: } 13 \%\end{array}$ \\
\hline
\end{tabular}

Abbreviations: IAC, intra-abdominal candidiasis; IC, invasive candidiasis.

\section{Candida susceptibility to antifungals in invasive candidiasis affecting liver disease patients}

In spite of antifungal therapy, mortality can exceed $30 \%-40 \%$ in IC patients. ${ }^{18}$ Due to the increased dispensing of fluconazole for treating candidemia in LTRs with IC, resistance to fluconazole has reached $57 \%$ mostly among non-albicans Candida spp., and class effects of drug resistance among azoles have also been reported. ${ }^{41,44,45}$

More recently, emerging resistance to echinocandins among $C$. glabrata has also been observed. ${ }^{46}$ Elevation of chitin levels in C. albicans cell wall was shown to decrease echinocandin's susceptibility in vitro, and in vivo resistance to caspofungin was observed in both isolates of C. albicans and non-albicans (e.g., C. parapsilosis and C. krusei). ${ }^{47,48}$ Above all, echinocandin resistance is significant among LTRs with IAC (4.8\%), especially in those under long exposure. ${ }^{28,49,50}$ This may be attributed to the development of point mutations of FKS genes among resistant species..$^{51}$

Although echinocandin-resistant isolates are rare in the Asian setting, evidence suggests that non-albicans species such as $C$. tropicalis and C. glabrata are becoming more resistant to echinocandins due to $F K S$ mutations. ${ }^{52}$ Moreover, C. parapsilosis has higher minimal inhibitory concentration
(MIC) to echinocandins than others, and the effects of echinocandins on C. parapsilosis are inconstant. ${ }^{53}$ In clinical trials, however, there has been a response to most $C$. parapsilosis complex infections with echinocandin therapy, regardless of reduced in vitro susceptibility. ${ }^{54}$ This may be probably explained by the species' relatively lower virulence. ${ }^{54}$ The recent emergence of novel species aggravates resistance, for example, C. auris, which is resistant to multiple classes of drugs including echinocandins. ${ }^{55}$

In a recent retrospective study of candidemia and IAC in patients with liver cirrhosis, higher mortality rates were associated with $C$. tropicalis candidemia compared to $C$. parapsilosis. ${ }^{30}$ C. tropicalis is considered highly virulent due to its ability to form true hyphae, complex biofilm in vitro and produce proteinases, phospholipases and hemolysins. ${ }^{56}$

\section{Formation of biofilms by Candida}

Candida infections can form biofilms on both biotic and abiotic surfaces. ${ }^{57}$ Biofilm formation by Candida spp. is clinically associated with higher mortality and currently there is no reference method available for antifungal susceptibility testing of biofilms. ${ }^{58,59}$ Central venous catheters (CVCs) and peripherally inserted central catheters are the common sites of biofilm formation by Candida spp. in nosocomial environments that persist as a reservoir of infective cells and may even inhibit the entry of antifungal drugs into the matrix..$^{58,60,61}$ The problem is further exacerbated due to different complex mechanisms for each species, which are still not fully known. ${ }^{62,63}$ Biofilm formation is more frequently reported in non-albicans, especially C. tropicalis (70\%) and C. glabrata (63.6\%) compared to C. albicans $(26.2 \%) .{ }^{64}$ C. auris also has strong biofilm forming capability, which even renders echinocandins inactive. ${ }^{65-67}$

Medical devices such as urinary catheters and CVCs are particularly prone to forming biofilms as they can act as potential substrates for fungal growth. ${ }^{68}$ Since hepatic patients in the ICU setting often need medical devices such as CVCs, biofilm formation by Candida spp. is highly relevant as it can potentially complicate the implications of candidiasis in LD patients.

Studies have demonstrated that adherent host immune cells may actively produce factors that promote biofilm formation of C. albicans. ${ }^{69}$ Biofilms can also act as an interactive physiological shear, where leucocytes can adhere and generate pro-inflammatory cytokines while downregulating other anti-inflammatory cytokines to render a favorable environment for biofilm growth. ${ }^{69,70}$ In advanced LD patients, 
systemic inflammation is manifested as a form of activated circulating immune cells and increased serum levels of proinflammatory cytokines, which in turn increases the likelihood of biofilm formation. ${ }^{5}$

\section{Diagnosis}

Delayed diagnosis of Candida infection among LD patients is associated with a poor prognosis and high mortality. ${ }^{71}$ Timely initiation of antifungal treatment for IC can improve patient outcomes and health care costs. ${ }^{72,73}$ It follows that established early diagnosis through risk factor analysis, epidemiology and novel predictive markers are all important to determine the timely use of antifungal agents in these patients. ${ }^{74,75}$

Diagnosis of IC is largely based on blood culture, although it can be nonspecific, insensitive and takes at least 48-72 hours due to slow multiplication rate of Candida. ${ }^{39,76}$ Blood cultures may take much longer than nonculture tests to diagnose IC, and sensitivity for blood culture was lowest $(17 \%)$ compared to other non-culture methods such as $(1,3)-\beta$-D-glucan (BDG) (62\%) and PCR (88\%) for deepseated candidiasis. ${ }^{77,78}$ Some clinical guidelines and studies suggest that BDG could be used to establish IC in LTRs and correlates with higher mortality. ${ }^{79}$ Combination of mannan antigen and anti-mannan antibody had sensitivity of $83 \%$ and specificity of $86 \%{ }^{56} \mathrm{~A}$ meta-analysis of PCR-based methods on blood samples for the diagnosis of IC reported an overall sensitivity and specificity of 0.95 (95\% CI: $0.88-0.98$ ) and 0.92 (95\% CI $0.88-0.95)$, respectively. ${ }^{80}$ However, various different assays were included. The performance of individual assays varied with sensitivity as low as 0.77 . Additional standardization is required to optimize the utility of PCR-based tests in the diagnosis of IC.

Although non-invasive tests can facilitate diagnosis, they are not superior compared to blood culture, which is the current gold standard. ${ }^{81}$ They may still lack sensitivity, specificity or both, and are unable to differentiate between active infection and inactive/dormant stage of microbes. ${ }^{77}$ The aforementioned disadvantages of currently available invasive and non-invasive diagnostic tools principally contribute to a delay in diagnosis. Table 3 lists various advantages and disadvantages of the diagnostic tests for IC in LD and liver transplantation patients.

As delayed culture report results can postpone treatment initiation and increase morbidity and mortality, many

Table 3 Advantages and disadvantages of invasive and non-invasive diagnostic tests for invasive candidiasis in liver disease and liver transplantation patients

\begin{tabular}{|c|c|c|}
\hline Diagnostic tests & Advantages & Disadvantages \\
\hline \multicolumn{3}{|l|}{ Non-invasive tests } \\
\hline$(1,3)-\beta$-D-glucan & $\begin{array}{l}\text { - Useful for ruling out a diagnosis of IFI (high negative } \\
\text { predictive value) })^{142}\end{array}$ & $\begin{array}{l}\text { - False positive common in ICU patients }{ }^{143} \\
\text { - False negative found for some Candida spp. such as C. parapsilosis } \\
\text { - Limited sensitivity and poor positive predictive value in LTRs }{ }^{144}\end{array}$ \\
\hline Galactomannan & $\begin{array}{l}\text { - High negative prediction values for LD patients even } \\
\text { for children }{ }^{145}\end{array}$ & $\begin{array}{l}\text { - Limited clinical utility and false negative common in LTRs }{ }^{146} \\
\text { - Interference with piperacillin-tazobactam (false positive) }{ }^{146,147}\end{array}$ \\
\hline Real-time PCR & $\begin{array}{l}\text { - Highly specific and sensitive for suspected IC } \\
\text { patients }{ }^{80} \\
\text { - Fastest among all diagnostic tests, allowing prompt } \\
\text { definitive therapy for critically ill patients }{ }^{145}\end{array}$ & - No reference standard and approved validation ${ }^{148}$ \\
\hline \multicolumn{3}{|l|}{ Invasive tests } \\
\hline Blood culture & - Gold standard for $\mathrm{IC}^{75}$ & $\begin{array}{l}\text { - Long incubation time } \\
\text { - Limited sensitivity for deep-seated candidiasis }{ }^{77,149} \\
\text { - C. glabrata takes longer time to positivity than C. albicans in IC } \\
\text { patients }{ }^{150}\end{array}$ \\
\hline $\begin{array}{l}\text { Peritoneal fluid } \\
\text { culture }\end{array}$ & $\begin{array}{l}\text { - Gold standard for diagnosis of SFP151 } \\
\text { - Good sensitivity, positive and negative predictive } \\
\text { values for peritonitis observed in ICU patients with } \\
\text { high risk factors }{ }^{152} \\
\text { - Associated with mortality in ICU patients }{ }^{153} \\
\text { - Easy to differentiate between SFP and peritonitis } \\
\text { resulting from preexisting liver disease }{ }^{154}\end{array}$ & $\begin{array}{l}\text { - Long turnover time for growth of Candida } \text { spp. }^{3} \\
\text { - Difficult to distinguish true Candida spp. from contaminants } \\
\text { - False negative due to culture techniques or prophylactic antifungal } \\
\text { treatments }{ }^{156}\end{array}$ \\
\hline
\end{tabular}

Abbreviations: IC, invasive candidiasis; ICU, intensive care unit; IFI, invasive fungal infection; LD, liver disease; LTRs, liver transplant recipients; SFP, spontaneous fungal peritonitis. 
risk prediction models for IC have been designed based on risk factors, clinical and microbiological parameters. These models are used for identifying high-risk groups and help in the early initiation of antifungal therapy. These include the Candida score and Candida colonization index. The Candida score targets ICU patients with length-of-stay $>7$ days. Four parameters are included in the Candida score (multifocal colonization, 1 point; surgery, 1 point; parenteral nutrition, 1 point; and severe sepsis, 2 points). A score $>3$ implies a high probability of developing IC (sensitivity: $77.6 \%$ and specificity: $66.2 \%) .{ }^{39}$ The Candida colonization index, which is a ratio of a division of a number of different body sites colonized by same strains by the total number of body sites investigated, is another score to predict the risk of developing IC (specificity: 79\%, sensitivity: 67\% and predictive validity: $66 \%) .{ }^{82,83}$ These scores have good negative predictive value (range: $84 \%-96 \%$ ) but have poor positive predictive value (range: $25 \%-47 \%$ ). ${ }^{84}$ These risk models are more useful in identifying patients who are unlikely to benefit from antifungal therapy and help minimize unnecessary use of antifungal agents. ${ }^{84}$ Traditionally, these risk models are used for evaluating patients admitted to ICU. Although these scoring systems provide a framework for assessing risk factors for IC, the applicability of these scoring systems in patients with chronic LD has not been validated. Further evaluation of risk factors for IC in this unique patient group is required to establish appropriate risk scoring tools.

Antifungal susceptibility testing of fungal species determines the MIC, which may predict the likelihood of efficacy of the antifungal therapy. ${ }^{85}$ However, caspofungin susceptibility testing has been reported to have limited reproducibility between different testing laboratories. ${ }^{86}$ In addition, characteristic mutations in FKS genes among non-albicans isolates is the only independent risk factor of failure of echinocandins, and testing for $F K S$ mutations can be a better predictor of therapeutic responses as well as indicator of likelihood of treatment success for echinocandins. ${ }^{87}$

\section{Role of echinocandins in invasive candidiasis}

With increasing prevalence of azole-resistant non-albicans spp., most guidelines recommend echinocandins as a firstline treatment for IC, especially in critically ill patients. ${ }^{88,89}$ Generally low MICs of echinocandins for all Candida spp. and low resistance compared to azoles make them favorable for eradication of different Candida spp. ${ }^{90}$

Echinocandins are also active within biofilms. ${ }^{91}$ However, definitive treatment should be always modified according to the culture data, and stepdown definitive therapy to azole should be considered if possible. ${ }^{92,93}$

Empirical treatment presupposes the likelihood of microbial infection and is largely driven by the minimal indications such as fever. ${ }^{23}$ However, inappropriate choice of antifungals for empirical therapy for IC can increase selective pressure of Candida and hence result in microbial resistance.

The American Association for the Study of Liver Diseases and the American Society of Transplantation particularly recommend caspofungin for prophylactic usage in LD patients with high risks such as those who would undergo choledochojejunostomy or re-transplantation..$^{94}$ The guidelines, however, do not differentiate among caspofungin, anidulafungin and micafungin for treatment of $\mathrm{IC}$, as none of them is found to be superior to the other. ${ }^{95,96}$ It is also important to note that there are differences in approved indications, for instance, anidulafungin is not approved for prophylaxis of IC or for pediatric use.

\section{Echinocandins: similar yet different}

There are currently no data demonstrating head-to-head superiority among echinocandins. Some limited retrospective studies, including a switching study in cancer patients with hepatotoxicity, have, however, observed an improvement in liver function after switching patients from caspofungin to anidulafungin..$^{97,98}$

Yet, there are still differences in structure, pharmacokinetics and pharmacodynamics, which may have potential implications on drug selections. Table 4 compares these features among the three available echinocandins for management of IC.

Echinocandins comprise of a cyclic lipopeptide core (nucleus) with an N-linked acyl fatty acid chain, which is the most important structural feature of this class. ${ }^{99}$ Structurally, anidulafungin's side chain is markedly lipophilic in comparison with the side chains of the other two echinocandins. ${ }^{99}$ Unlike caspofungin and micafungin, anidulafungin's metabolic pathway does not involve liver and it is rather spontaneously degraded by itself in plasma. ${ }^{100}$ Also unlike caspofungin and micafungin, which are readily soluble in plasma, anidulafungin does not freely dissolve in plasma. ${ }^{101}$ These differences probably account for anidulafungin's longer distribution (due to the lipophilic side chain) and mean elimination half-lives (due to slow degradation in plasma) as well as greater volume of distribution. Table 4 summarizes a detailed comparison among the three echinocandins for treatment of IC. 
Table 4 Comparison of echinocandins for treatment of invasive candidiasis

\begin{tabular}{|c|c|c|c|}
\hline Parameter & Caspofungin & Micafungin & Anidulafungin \\
\hline Structure $^{99}$ & $\begin{array}{l}\mathrm{C} 56 \mathrm{H} 96 \mathrm{~N} 10 \mathrm{O} 19 \\
\text { Side chain: fatty acid }\end{array}$ & $\begin{array}{l}\mathrm{C} 56 \mathrm{H} 70 \mathrm{~N} 9 \mathrm{NaO} 23 \mathrm{~S} \\
\text { Side chain: aromatic } \\
\text { (3,5-diphenyl-substituted } \\
\text { isoxazole) }\end{array}$ & $\begin{array}{l}\text { C58H73N7OI } \\
\text { Side chain: lipophilic alkoxytriphenyl } \\
\text { (terphenyl) }\end{array}$ \\
\hline Metabolism $^{106}$ & $\begin{array}{l}\text { Liver metabolism via peptide } \\
\text { hydrolysis and } \mathrm{N} \text {-acetylation }\end{array}$ & $\begin{array}{l}\text { Liver metabolism via } \\
\text { arylsulfatase and COMT }\end{array}$ & $\begin{array}{l}\text { No liver metabolism-slow } \\
\text { degradation in plasma } \\
\text { Degraded products eliminated into } \\
\text { feces by biliary route }\end{array}$ \\
\hline Protein binding ${ }^{101}$ & $>95 \%$ & $>99 \%$ & $>99 \%$ \\
\hline Pharmacokinetics ${ }^{100,106,121,157}$ & $\begin{array}{l}\text { Cmax (ug/mL): I } \\
\text { AUC (ug h/mL): I I8 } \\
C L(\mathrm{~mL} / \mathrm{min}): 10-12.5 \\
\text { Total half-life (hours) : 8-10 } \\
\text { Mean elimination half-life } \\
\text { (hours): } 8-10 \\
\text { VD (L): } 9.67\end{array}$ & $\begin{array}{l}\text { Cmax (ug/mL): } 18 \\
\text { AUC (ug h/mL): } 101.6 \\
C L(\mathrm{~mL} / \mathrm{min}): 10.5 \\
\text { Total half-life (hours): } 13-20 \\
\text { Mean elimination half-life } \\
\text { (hours): } 12-17 \\
\text { VD (L): } 18-19\end{array}$ & $\begin{array}{l}\text { Cmax (ug/mL): } 7.7 \\
\text { AUC (ug h/mL): } 106 \\
C L(\mathrm{~mL} / \mathrm{min}): 16.67 \\
\text { Total half-life (hours): } 40-50 \\
\text { Mean elimination } \\
\text { half-life (hours): } 24-26 \\
\text { VD (L): 30-50 }\end{array}$ \\
\hline Pharmacodynamics ${ }^{103-105,158}$ & $\begin{array}{l}\text { AUC/MIC: } \\
\text { For C. glabrata: } \\
\text { - Wild type: } 2.04 \\
\text { - FKS mutation: } 2.67 \\
\text { PAFE: } \\
\text { For C. albicans: }>12 \text { hours at } \\
>\text { MIC } \\
\text { For C. parapsilosis: } 33->120 \\
\text { hours at MIC } \\
\text { For C. glabrata: }>120 \text { hours at } \\
2 \times \text { MIC }\end{array}$ & $\begin{array}{l}\text { AUC/MIC: } \\
\text { For C. glabrata: } \\
\text { - Wild type: } 6.78 \\
\text { - FKS mutation: } 0.90 \\
\text { PAFE: } \\
\text { For C. albicans: Shorter than the } \\
\text { other two agents ( } 9.8 \text { hours on } \\
\text { average) } \\
\text { For C. parapsilosis: } 0-8 \text { hours } \\
\text { at MIC } \\
\text { For C. krusei: }>20.1 \text { hours* } \\
\text { was observed at } 4 \times \text { MIC } \\
\text { concentration }\end{array}$ & $\begin{array}{l}\text { AUC/MIC: } \\
\text { For C. glabrata: } \\
\text { - Wild type: } 13.2 \\
\text { - FKS mutation: } 3.43 \\
\text { PAFE: } \\
\text { For C. albicans: }>12 \text { hours, at }>\text { MIC, } \\
\text { PAFE even observed at sub-MIC } \\
\text { concentration } \\
\text { For } C \text {. parapsilosis: } 33->120 \text { hours } \\
\text { at MIC, but longer than caspofungin } \\
\text { when } 2 \times \text { MIC } \\
\text { For } C \text {. glabrata: }>120 \text { hours at } 2 x \\
\text { MIC }\end{array}$ \\
\hline Dose $^{114,137}$ & $\begin{array}{l}70 \mathrm{mg} \text { as a single loading dose } \\
\text { on first day, followed by a } \\
\text { maintenance dose of } 50 \mathrm{mg} \\
\text { once daily } \\
\text { or } \\
70 \mathrm{mg} \text { once daily, when the } \\
\text { body weight exceeds } 80 \mathrm{~kg}\end{array}$ & $\begin{array}{l}\text { I00 mg once daily } \\
\text { No loading dose required }\end{array}$ & $\begin{array}{l}200 \mathrm{mg} \text { as a single loading dose on } \\
\text { first day, followed by } 100 \mathrm{mg} \text { dose } \\
\text { once daily }\end{array}$ \\
\hline $\begin{array}{l}\text { Dosing in renal patients } \\
\text { without replacement therapy }\end{array}$ & No dosing adjustment needed & No dosing adjustment needed & No dose adjustment needed \\
\hline $\begin{array}{l}\text { Dosing in renal patients with } \\
\text { replacement therapy }{ }^{15,159-164}\end{array}$ & $\begin{array}{l}\text { Generally no dosing } \\
\text { adjustment is needed. } \\
\text { However, in critically ill } \\
\text { patients on continuous } \\
\text { venovenous hemodiafiltration, } \\
\text { dose escalation to } 100 \mathrm{mg} \\
\text { (loading dose) or } 200 \mathrm{mg} \\
\text { once daily may be required }\end{array}$ & $\begin{array}{l}\text { No dose adjustment is required } \\
\text { for patients undergoing } \\
\text { continuous renal replacement } \\
\text { therapy } \\
\text { However, increase in dose is } \\
\text { recommended after 8-hour } \\
\text { plasma exchange therapy }\end{array}$ & $\begin{array}{l}\text { Filter absorption is observed yet } \\
\text { clinical significance is unknown } \\
\text { No dosing adjustment is needed }\end{array}$ \\
\hline 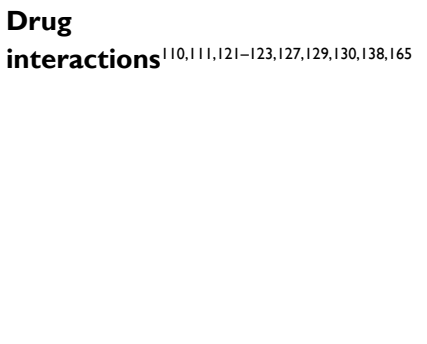 & $\begin{array}{l}\text { - Powerful CYP inducers } \\
\text { or inhibitors* (clinically } \\
\text { insignificant) } \\
\text { - Rifampicin (clinically } \\
\text { significant) } \\
\text { - Tacrolimus (clinically } \\
\text { significant) } \\
\text { - Cyclosporine (clinically } \\
\text { significant) }\end{array}$ & $\begin{array}{l}\text { - Cyclosporine (clinically } \\
\text { significant) } \\
\text { - Sirolimus, nifedipine (clinically } \\
\text { insignificant) }\end{array}$ & $\begin{array}{l}\text { - Cyclosporine (clinically } \\
\text { insignificant) }\end{array}$ \\
\hline
\end{tabular}


Table 4 (Continued)

\begin{tabular}{|c|c|c|c|}
\hline Parameter & Caspofungin & Micafungin & Anidulafungin \\
\hline $\begin{array}{l}\text { Precautions and } \\
\text { contraindications }^{106,166-168}\end{array}$ & $\begin{array}{l}\text { - Relatively safe } \\
\text { - Common ADR (>I0\%): } \\
\text { diarrhea, pyrexia, increase } \\
\text { in liver enzymes (AST/ } \\
\text { ALT) and serum alkaline } \\
\text { phosphatase }\end{array}$ & $\begin{array}{l}\text { - Common ADR (>I0\%): fever, } \\
\text { infusion-related reaction, } \\
\text { phlebitis, skin rash } \\
\text { - Hepatotoxicity (unknown } \\
\text { incidence) } \\
\text { - Hepatocellular tumors } \\
\text { found in vitro in rats when } \\
\text { micafungin is given for more } \\
\text { than } 3 \text { months } \\
\text { - Restricted indication, to be } \\
\text { used only if other agents are } \\
\text { not appropriate }\end{array}$ & $\begin{array}{l}\text { - Safe } \\
\text { - Less frequent ADR ( } 1 \%-4 \%) \text { : } \\
\text { hypokalemia, nausea and vomiting }\end{array}$ \\
\hline
\end{tabular}

Note: *For example, phenytoin, carbamazepine, nevirapine, nelfinavir, dexamethasone.

Abbreviations: ADR, adverse drug reaction; ALT, alanine aminotransferase; AST, aspartate transaminase; $A U C$, area under the curve; CL, clearance; COMT, catecholO-methyltransferase; MIC, minimum inhibitory concentration; PAFE, post-antifungal effects; VD, volume of distribution.

In a study comparing the in vitro activity of echinocandins, the MIC of caspofungin for C. albicans was found to be greater than the MIC of micafungin and anidulafungin. ${ }^{102}$ Caspofungin also showed the weakest sterilizing activity compared to the other two echinocandins. ${ }^{102}$ Another study reported that the $\mathrm{AUC} / \mathrm{MIC}$ for anidulafungin is greater than the other two echinocandins for both wild-type and $F K S$ mutated C. glabrata. ${ }^{103}$ Although post-anti-fungal effects (PAFE) are variable depending upon MIC concentration as well as Candida spp., PAFE of anidulafungin and caspofungin is reported to be longer than that of micafungin for $C$. albicans and C. parapsilosis. ${ }^{104,105}$

\section{Differences among echinocandins in liver disease patients}

Pharmacokinetics (PK) of echinocandins, especially with regards to metabolism and elimination, can be affected by hepatic impairment in LD patients. ${ }^{106}$ Multiple organ failure is also common in LD patients, mostly triggered by viral hepatitis and alcoholic hepatitis. ${ }^{107}$ One retrospective study reported that $94 \%$ of the patients with cirrhosis required admission to the ICU within a 10 -year period. ${ }^{108} \mathrm{LD}$ patients admitted to ICU have a reported mortality rate of 34\%-69\%. ${ }^{109,110}$

Half to one-third of Candida infections also occur in critically ill (ICU) patients where pathophysiological alterations in terms of hemodynamics and plasma protein levels also modify the distribution of the drugs. ${ }^{106,111}$ Therefore, PK of drugs in LD patients, especially those who are critically ill, can appear to be variable and difficult to predict. ${ }^{106}$ Table 5 summarizes the PK of echinocandins in LD and critically ill patients.

\section{Caspofungin}

Caspofungin is transformed in the liver. It is hydrolyzed to M0 (main metabolite) and M1. M2 is formed by N-acetylation of M1. These metabolites are then eliminated via urine. A slight elevation in caspofungin concentrations has been observed in mild hepatic insufficiency, but was judged as clinically irrelevant. For patients with moderate hepatic impairment, reduction of the maintenance dose to $35 \mathrm{mg} / \mathrm{d}$ is required. However, dose reduction in critically ill patients with moderate hepatic dysfunction may achieve sub-therapeutic caspofungin exposure and efficacy if the dose is adjusted. This is probably because of hypoalbuminemia and effects of low albumin levels on caspofungin metabolism. ${ }^{12,113}$ Advanced LD is also associated with hypoalbuminemia and a similar trend may also be observed.

Among surgical ICU patients, higher exposure of caspofungin was observed in one study. ${ }^{114}$ However, in the nonsurgical ICU setting, caspofungin PK was comparable to that in non-critically ill patients. ${ }^{115,116}$

Although there are few drug interactions with echinocandins in general, caspofungin interacts the most with other medications among the three echinocandin drugs. Caspofungin is a poor substrate for cytochrome P450 enzymes, hence co-administration with powerful CYP inducers or inhibitors such as phenytoin and carbamazepine may result in altered clearance and plasma concentration, which are found to be clinically insignificant. However, there have been speculations that caspofungin may interact with halogenated penicillins such as flucloxacillin, nafcillin and dicloxacillin as they have potential to induce CYP3A4 enzyme. ${ }^{117-120}$ Drugs interactions with rifampicin 
Table 5 Pharmacokinetics of echinocandins in LD patients

\begin{tabular}{|c|c|c|}
\hline Study & Study characteristics & PK in LD patients \\
\hline \multicolumn{3}{|l|}{ Caspofungin } \\
\hline Mistry et al $\left.\right|^{1 / 2}$ & $\begin{array}{l}\text { Single-dose, open-label study of } 70 \mathrm{mg} \text { per day } \\
\text { for } 14 \text { days }\end{array}$ & $\begin{array}{l}\text { - Increased AUC, Cmin and } \beta \text {-phase half-life compared with the healthy control } \\
\text { subjects } \\
\text { - Dose reduction to } 35 \mathrm{mg} \text { daily following } 70 \mathrm{mg} \text { is recommended for moderate } \\
\text { and severe LD patients }\end{array}$ \\
\hline Spriet et al 169 & $\begin{array}{l}\text { Case study of ICU patient with Child-Pugh } \\
\text { score B9 ( } 70 \mathrm{mg} \text { on day I followed by } \\
\text { maintenance dose of } 50 \mathrm{mg} / \text { day) }\end{array}$ & $\begin{array}{l}\text { - AUC is comparable to that of healthy subjects (no higher systemic exposure is } \\
\text { observed) } \\
\text { - Dose reduction is not recommended }\end{array}$ \\
\hline Spriet et al $\left.\right|^{169}$ & $\begin{array}{l}\text { Case study of ICU patient with Child A } \\
\text { liver cirrhosis and transjugular intrahepatic } \\
\text { portosystemic shunt }\end{array}$ & $\begin{array}{l}\text { - Similar exposure and PK parameters compared to the healthy volunteers } \\
\text { - Dose reduction not recommended }\end{array}$ \\
\hline \multicolumn{3}{|l|}{ Micafungin } \\
\hline Undre et al ${ }^{124}$ & $\begin{array}{l}\text { Single dose, open-label with severe hepatic } \\
\text { dysfunction (Child-Pugh score 10-12) }\end{array}$ & $\begin{array}{l}\text { - Low Cmax, low AUC in severe LD patients compared to healthy subjects (not } \\
\text { clinically relevant) }\end{array}$ \\
\hline Hebert et al $\left.\right|^{125}$ & $\begin{array}{l}\text { Phase I, parallel-group, open-label PK study } \\
\text { of single dose IV micafungin in eight moderate } \\
\text { LD patients (Child-Pugh score 7-9) }\end{array}$ & $\begin{array}{l}\text { - Lower AUC, Cmax in moderate LD patients compared to healthy volunteers, } \\
\text { but no difference in clearance and volume of distribution or half-life } \\
\text { - No change in unbound plasma concentration compared to that of healthy } \\
\text { controls. } \\
\text { - Given that low AUC is attributed to weight difference, dose reduction is not } \\
\text { recommended }\end{array}$ \\
\hline \multicolumn{3}{|l|}{ Anidulafungin } \\
\hline Dowell et al ${ }^{133}$ & $\begin{array}{l}\text { Phase I, open-label, single-dose prospective } \\
\text { study in adult patients at two clinical sites }\end{array}$ & $\begin{array}{l}\text { PK parameters of mild and moderate LD patients were comparable to healthy } \\
\text { controls. Decreases in AUC and Cmax in severe LD patients were observed } \\
\text { compared to healthy subjects (not clinically relevant, probably due to increase in } \\
\text { VD due to ascites and edema). However, half-life in LD patients was comparable } \\
\text { to healthy subjects }\end{array}$ \\
\hline
\end{tabular}

Abbreviations: AUC, area under the curve; ICU, intensive care unit; LD, liver disease; PK, pharmacokinetics; VD, volume of distribution; $\beta$-phase half-life, elimination half-life.

have also been documented. A momentary increase in AUC (61\% increase) of caspofungin was found on day 1 , while its trough concentration dropped to $14 \%-31 \%$ after 14 days. ${ }^{121}$ Dose adjustment of tacrolimus may also be necessary as reduction of Cmax of tacrolimus (up to 20\%) was observed when co-administered with caspofungin. ${ }^{122}$ The most relevant drug interaction is with cyclosporine; co-administration with cyclosporine increases the plasma concentration of caspofungin up to $35 \% .{ }^{123}$

\section{Micafungin}

Micafungin is metabolized in the liver by non-CYP enzymes largely into the inactive metabolites $\mathrm{M}-1, \mathrm{M}-2$ and $\mathrm{M}-5$. These metabolites are excreted mainly via feces. ${ }^{106}$ It is also a weak inhibitor of CYP3A, but its clinical significance is unknown. ${ }^{106}$

Micafungin is known to have low hepatic extraction ratio with high plasma protein binding, and hence theoretically although its total plasma concentration may decrease in some clinical scenarios, its unbound concentration is likely to remain the same at steady state level. ${ }^{124}$ However, as these enzymes are also present in other organs besides the liver, the extent of the overall impact of impairment in these enzymes in LD patients that will contribute to the metabolism of these drugs is unknown. ${ }^{125}$ While lower AUC in moderate and severe LD patients has been reported, the changes are however clinically irrelevant and dose adjustments are not recommended for any severity of LD patients. ${ }^{125}$

In some studies, increase in micafungin clearance was observed due to decreased protein binding resulting from low albumin levels in LD patients; the clinical relevance in LD patients is, however, not conclusive. ${ }^{126}$

The PK of micafungin is very well defined in noncritically ill patients and seems to be similar in critically ill patients. ${ }^{127}$ However, increase in dose is recommended for critically ill patients infected with higher MIC Candida spp or C. parapsilosis. ${ }^{126}$ With regards to $\mathrm{PK}$ of micafungin in ICU patients, AUC is reported to be lower than the reference population, and strong positive correlation of AUC and sequential organ failure assessment (SOFA) score as well as negative correlation of AUC level and body weight has been observed. ${ }^{128}$

The most clinically significant drug interaction is with cyclosporine. A $15 \%$ reduction in clearance of cyclosporine 
when co-administered with micafungin was observed to be clinically significant. ${ }^{129}$ Although interactions with nifedipine and sirolimus have not been widely mentioned in the literature, there are speculations that they may affect the PK of micafungin, and hence caution should be applied when micafungin is given with these medications concomitantly. ${ }^{130}$

Hepatotoxicity and potential for hepatic tumors, however, is a concern with micafungin. ${ }^{106}$ Abnormal liver function tests have been noted after administration of micafungin to healthy volunteers. In rats, foci of altered hepatocytes and hepatocellular tumors were found to emerge with micafungin exposure after 3 months. ${ }^{100}$ Therefore, the European Medicines Agency and other regulatory authorities have restricted the indication of micafungin as follows: "The decision to use Mycamine should take into account a potential risk for the development of liver tumors. Mycamine should therefore only be used if other antifungals are not appropriate". ${ }^{131,132}$

\section{Anidulafungin}

Anidulafungin undergoes non-hepatic slow degradation and the metabolites are eliminated via biliary excretion in feces. No difference in anidulafungin PK was observed in LD patients compared to that in the healthy volunteers, implying that no dose adjustment is needed. ${ }^{121}$ Statistically significant yet not clinically relevant decreases of AUC and Cmax were, however, found in patients with severe LD compared to healthy controls. ${ }^{133}$ This was attributed to ascites and edema, leading to increase in volume of distribution.

In critically ill patients, anidulafungin exposure was slightly lower yet comparable to healthy volunteers. ${ }^{134,135}$ Also, the Model for End-Stage Liver Disease score and albumin levels were not found to affect the PK of anidulafungin in critically ill patients. ${ }^{136}$ This slightly low exposure of anidulafungin in critically ill patients was attributed to many different factors such as body weight, body water volume and altered renal clearance. ${ }^{137}$

Not many drug interactions with concomitant medications have been known except a slight increase in AUC when coadministered with cyclosporine, which was found clinically insignificant. ${ }^{138}$

\section{Conclusion}

The precise differences between the three echinocandins in the antifungal armamentarium are still unfolding. There is no prospective comparative efficacy and safety data for echinocandins and hence the guidelines do not differentiate the echinocandins for management of IC. Conversely, there are major pharmacokinetic and pharmacodynamic differences within three echinocandins that are likely to play an important role in selection of appropriate agents especially in patients with LD. Hence, the "one-size-fits-all-approach" may be successful for some patients but may not be successful for management of IC in LD patients. Careful selection of appropriate echinocandin is required in this subset of patients to achieve the goal of precision medicine to target the right medicine to the right patient. Among the three echinocandins, anidulafungin has possible advantages mainly due to its unique non-hepatic metabolism, more predictable PK and good tolerability. However, this needs to be further supported by future large-scale prospective comparative studies.

\section{Acknowledgments}

The authors would like to thank Dr. Deborah J Marriott, Department of Microbiology and Infectious Diseases, St Vincent's Hospital, Australia, for her valuable comments during design of the manuscript. The authors would also like to thank Ms. Tanaya Bharatan, Pfizer, for her editorial support for this manuscript.

\section{Author contributions}

All the authors were involved in conception, design, analysis and interpretation of data. All the authors were also involved in preparation of the manuscript, revising it for important intellectual content and final approval before submitting for publication.

\section{Disclosure}

Dr. Stephen Lin, Mr. Dennis Yeo and Dr. Sajita Setia are employees of Pfizer, manufacturer of anidulafungin. Mr. Tae Jin Lee underwent indirect patient care pharmacy training for 3 months at Pfizer, Singapore. The other authors report no conflicts of interest in this work.

\section{References}

1. Potosek J, Curry M, Buss M, Chittenden E. Integration of palliative care in end-stage liver disease and liver transplantation. J Palliat Med. 2014;17(11):1271-1277.

2. Agarwal S, Joyner KA Jr, Swaim MW. Ascites fluid as a possible origin for hyperfibrinolysis in advanced liver disease. Am J Gastroenterol. 2000;95(11):3218-3224.

3. Hassan EA, Abd El-Rehim AS, Hassany SM, Ahmed AO, Elsherbiny NM, Mohammed MH. Fungal infection in patients with end-stage liver disease: low frequency or low index of suspicion. Int $J$ Infect Dis. 2014;23:69-74.

4. Verma A, Auzinger G, Kantecki M, et al. Safety and efficacy of anidulafungin for fungal infection in patients with liver dysfunction or multiorgan failure. Open Forum Infect Dis. 2017;4(1):ofw241.

5. Albillos A, Lario M, Álvarez-Mon M. Cirrhosis-associated immune dysfunction: distinctive features and clinical relevance. J Hepat. 2014;61(6):1385-1396. 
6. Papp M, Vitalis Z, Altorjay I, et al. Acute phase proteins in the diagnosis and prediction of cirrhosis associated bacterial infections. Liver Int. 2012;32(4):603-611.

7. Bernsmeier C, Pop OT, Singanayagam A, et al. Patients with acuteon-chronic liver failure have increased numbers of regulatory immune cells expressing the receptor tyrosine kinase MERTK. Gastroenterology. 2015;148(3):603-615.e614.

8. Karakike E, Moreno C, Gustot T. Infections in severe alcoholic hepatitis. Ann Gastroenterol. 2017;30(2):152-160.

9. Lahmer T, Messer M, Schwerdtfeger C, et al. Invasive mycosis in medical intensive care unit patients with severe alcoholic hepatitis. Mycopathologia. 2014;177(3-4):193-197.

10. Thursz MR, Richardson P, Allison M, et al. Prednisolone or pentoxifylline for alcoholic hepatitis. N Engl J Med. 2015;372(17):1619-1628.

11. Dhanda AD, Sinha A, Hunt V, Saleem S, Cramp ME, Collins PL. Infection does not increase long-term mortality in patients with acute severe alcoholic hepatitis treated with corticosteroids. World J Gastroenterol. 2017;23(11):2052-2059.

12. Lucey MR, Mathurin P, Morgan TR. Alcoholic hepatitis. $N$ Engl J Med. 2009;360(26):2758-2769.

13. Liu X, Ling Z, Li L, Ruan B. Invasive fungal infections in liver transplantation. Int J Infect Dis. 2011;15(5):e298-e304.

14. Zhou T, Xue F, Han LZ, et al. Invasive fungal infection after liver transplantation: risk factors and significance of immune cell function monitoring. J Dig Dis. 2011;12(6):467-475.

15. Antinori S, Milazzo L, Sollima S, Galli M, Corbellino M. Candidemia and invasive candidiasis in adults: a narrative review. Eur J Intern Med. 2016;34:21-28.

16. Vincent JL, Rello J, Marshall J, et al; EPIC II Group of Investigators. International study of the prevalence and outcomes of infection in intensive care units. JAMA. 2009;302(21):2323-2329.

17. Wisplinghoff H, BischoffT, Tallent SM, Seifert H, Wenzel RP, Edmond MB. Nosocomial bloodstream infections in US hospitals: analysis of 24,179 cases from a prospective nationwide surveillance study. Clin Infect Dis. 2004;39(3):309-317.

18. Kullberg BJ, Arendrup MC. Invasive candidiasis. $N$ Engl J Med. 2015;373(15):1445-1456.

19. Alexopoulou A, Vasilieva L, Agiasotelli D, Dourakis SP. Fungal infections in patients with cirrhosis. J Hepatol. 2015;63(4):1043-1045.

20. Bartoletti M, Giannella M, Lewis RE, Viale P. Bloodstream infections in patients with liver cirrhosis. Virulence. 2016;7(3):309-319.

21. Morrell M, Fraser VJ, Kollef MH. Delaying the empiric treatment of candida bloodstream infection until positive blood culture results are obtained: a potential risk factor for hospital mortality. Antimicrob Agents Chemother. 2005;49(9):3640-3645.

22. Pappas PG, Kauffman CA, Andes DR, et al. Clinical Practice Guideline for the Management of Candidiasis: 2016 Update by the Infectious Diseases Society of America. Clin Infect Dis. 2016;62(4):e1-e50.

23. Cornely OA, Bassetti M, Calandra T, et al; ESCMID Fungal Infection Study Group. ESCMID* guideline for the diagnosis and management of Candida diseases 2012: non-neutropenic adult patients. Clin Microbiol Infect. 2012;18 Supp1 7:19-37.

24. Leroy O, Bailly S, Gangneux JP, et al; AmarCAND2 study group. Systemic antifungal therapy for proven or suspected invasive candidiasis the AmarCAND 2 study. Ann Intensive Care. 2016;6(1):2.

25. Saif MW, Raj M. Cryptococcal peritonitis complicating hepatic failure: case report and review of the literature. J Appl Res. 2006;6(1):43-50.

26. Rolando N, Harvey F, Brahm J, et al. Fungal infection: a common, unrecognised complication of acute liver failure. J Hepatol. 1991;12(1):1-9.

27. Leber B, Spindelboeck W, Stadlbauer V. Infectious complications of acute and chronic liver disease. Semin Respir Crit Care Med. 2012;33(1):80-95.

28. Bassetti M, Peghin M, Carnelutti A, et al. Invasive Candida infections in liver transplant recipients: clinical features and risk factors for mortality. Transplant Direct. 2017;3(5):e156.

29. Bassetti M, Righi E, Ansaldi F, et al. A multicenter study of septic shock due to candidemia: outcomes and predictors of mortality. Intensive Care Med. 2014;40(6):839-845.
30. Bassetti M, Peghin M, Carnelutti A, et al. Clinical characteristics and predictors of mortality in cirrhotic patients with candidemia and intra-abdominal candidiasis: a multicenter study. Intensive Care Med. 2017;43(4):509-518.

31. Lahmer T, Brandl A, Rasch S, Schmid RM, Huber W. Fungal peritonitis: underestimated disease in critically ill patients with liver cirrhosis and spontaneous peritonitis. PLoS One. 2016;11(7):e0158389.

32. Gravito-Soares M, Gravito-Soares E, Lopes S, Ribeiro G, Figueiredo P. Spontaneous fungal peritonitis: a rare but severe complication of liver cirrhosis. Eur J Gastroenterol Hepatol. 2017;29(9):1010-1016.

33. Wang $\mathrm{H}, \mathrm{Xu}$ YC, Hsueh PR. Epidemiology of candidemia and antifungal susceptibility in invasive Candida species in the Asia-Pacific region. Future Microbiol. 2016;11:1461-1477.

34. Mikulska M, Del Bono V, Ratto S, Viscoli C. Occurrence, presentation and treatment of candidemia. Expert Rev Clin Immunol. 2012;8(8):755-765.

35. Cleveland AA, Harrison LH, Farley MM, et al. Declining incidence of candidemia and the shifting epidemiology of candida resistance in two US metropolitan areas, 2008-2013: results from population-based surveillance. PLoS One. 2015;10(3):e0120452.

36. Tan TY, Hsu LY, Alejandria MM, et al. Antifungal susceptibility of invasive Candida bloodstream isolates from the Asia-Pacific region. Med Mycol. 2016;54(5):471-477.

37. Tan BH, Chakrabarti A, Li RY, et al; Asia Fungal Working Group (AFWG). Incidence and species distribution of candidaemia in Asia: a laboratory-based surveillance study. Clin Microbiol Infect. 2015;21(10):946-953.

38. Teo JQ, Candra SR, Lee SJ, et al. Candidemia in a major regional tertiary referral hospital - epidemiology, practice patterns and outcomes. Antimicrob Resist Infect Control. 2017;6(1):27.

39. Candel FJ, Pacheco PC, Ruiz-Camps I, et al. Update on management of invasive candidiasis. Rev Esp Quimioter. 2017;30(6):397-406.

40. Medrano DJ, Brilhante RS, Cordeiro Rde A, Rocha MF, Rabenhorst SH, Sidrim JJ. Candidemia in a Brazilian hospital: the importance of Candida parapsilosis. Rev Inst Med Trop Sao Paulo. 2006;48(1):17-20.

41. Raghuram A, Restrepo A, Safadjou S, et al. Invasive fungal infections following liver transplantation: incidence, risk factors, survival, and impact of fluconazole-resistant Candida parapsilosis (2003-2007). Liver Transpl. 2012;18(9):1100-1109.

42. Pfaller MA, Diekema DJ; International Fungal Surveillance Participant Group. Twelve years of fluconazole in clinical practice: global trends in species distribution and fluconazole susceptibility of bloodstream isolates of Candida. Clin Microbiol Infect. 2004;10(Suppl 1):11-23.

43. Pfaller MA, Diekema DJ, Gibbs DL, et al. Results from the ARTEMIS DISK Global Antifungal Surveillance Study, 1997 to 2007: a 10.5year analysis of susceptibilities of Candida Species to fluconazole and voriconazole as determined by CLSI standardized disk diffusion. $J$ Clin Microbiol. 2010;48(4):1366-1377.

44. Sanglard D. Emerging threats in antifungal-resistant fungal pathogens. Front Med (Lausanne). 2016;3:11.

45. Vallabhaneni S, Cleveland AA, Farley MM, et al. Epidemiology and risk factors for echinocandin nonsusceptible Candida glabrata bloodstream infections: data from a large multisite population-based Candidemia Surveillance Program, 2008-2014. Open Forum Infect Dis. 2015;2(4):ofv163.

46. Perlin DS. Echinocandin resistance in Candida. Clin Infect Dis. 2015;61(Suppl 6):S612-S617.

47. Walker LA, Gow NA, Munro CA. Elevated chitin content reduces the susceptibility of Candida species to caspofungin. Antimicrob Agents Chemother. 2013;57(1):146-154.

48. Lee KK, Maccallum DM, Jacobsen MD, et al. Elevated cell wall chitin in Candida albicans confers echinocandin resistance in vivo. Antimicrob Agents Chemother. 2012;56(1):208-217.

49. Castanheira M, Messer SA, Rhomberg PR, Pfaller MA. Antifungal susceptibility patterns of a global collection of fungal isolates: results of the SENTRY Antifungal Surveillance Program (2013). Diagn Microbiol Infect Dis. 2016;85(2):200-204. 
50. Giacobino J, Montelli AC, Barretti P, et al. Fungal peritonitis in patients undergoing peritoneal dialysis (PD) in Brazil: molecular identification, biofilm production and antifungal susceptibility of the agents. Med Mycol. 2016;54(7):725-732.

51. Park S, Kelly R, Kahn JN, et al. Specific substitutions in the echinocandin target Fks1p account for reduced susceptibility of rare laboratory and clinical Candida sp. isolates. Antimicrob Agents Chemother. 2005;49(8):3264-3273.

52. Tan TY, Tan AL, Tee NW, Ng LS, Chee CW. The increased role of non-albicans species in candidaemia: results from a 3-year surveillance study. Mycoses. 2010;53(6):515-521.

53. Lin CC, Liu CP, Hsieh FC, Lee CM, Wang WS. Antimicrobial susceptibility and clinical outcomes of Candida parapsilosis bloodstream infections in a tertiary teaching hospital in Northern Taiwan. JMicrobiol Immunol Infect. 2015;48(5):552-558.

54. Reboli AC. Editorial commentary: Is the debate about treatment of Candida parapsilosis complex infections with echinocandins much ado about nothing? Clin Infect Dis. 2014;58(10):1422-1423.

55. Lockhart SR, Etienne KA, Vallabhaneni S, et al. Simultaneous emergence of multidrug-resistant Candida auris on 3 continents confirmed by whole-genome sequencing and epidemiological analyses. Clin Infect Dis. 2017;64(2):134-140.

56. Zuza-Alves DL, Silva-Rocha WP, Chaves GM. An update on Candida tropicalis based on basic and clinical approaches. Front Microbiol. 2017;8:1927.

57. Høiby N, Bjarnsholt T, Moser C, et al; ESCMID Study Group for Biofilms and Consulting External Expert Werner Zimmerli. ESCMID guideline for the diagnosis and treatment of biofilm infections 2014. Clin Microbiol Infect. 2015;21 Suppl 1:S1-S25.

58. Tascini C, Sozio E, Corte L, et al. The role of biofilm forming on mortality in patients with candidemia: a study derived from real world data. Infect Dis (Lond). 2018;50(3):214-219.

59. Prażyńska M, Bogiel T, Gospodarek-Komkowska E. In vitro activity of micafungin against biofilms of Candida albicans, Candida glabrata, and Candida parapsilosis at different stages of maturation. Folia Microbiol (Praha). 2018;63(2):209-216.

60. Corte L, Roscini L, Colabella C, et al. Exploring ecological modelling to investigate factors governing the colonization success in nosocomial environment of Candida albicans and other pathogenic yeasts. Sci Rep. 2016;6:26860.

61. Tascini C, Sozio E, Tintori G, et al. Peripherally inserted central catheter as a predominant risk factor for candidemia in critically ill patients in Internal Medicine wards in Italy. Intensive Care Med. 2015;41(8):1498-1499.

62. Borghi E, Borgo F, Morace G. Fungal biofilms: update on resistance. In: Imbert C, editor. Fungal Biofilms and Related Infections: Advances in Microbiology, Infectious Diseases and Public Health Volume 3. Cham: Springer International Publishing; 2016:37-47.

63. Fernandes T, Silva S, Henriques M. Candida tropicalis biofilm's matrix - involvement on its resistance to amphotericin B. Diagn Microbiol Infect Dis. 2015;83(2):165-169.

64. Tumbarello M, Fiori B, Trecarichi EM, et al. Risk factors and outcomes of candidemia caused by biofilm-forming isolates in a tertiary care hospital. PLoS One. 2012;7(3):e33705.

65. Borman AM, Szekely A, Johnson EM. Comparative pathogenicity of United Kingdom isolates of the emerging pathogen Candida auris and other key pathogenic Candida Species. mSphere. 2016;1(4):e00189-16.

66. Larkin E, Hager C, Chandra J, et al. The emerging pathogen Candida auris: growth phenotype, virulence factors, activity of antifungals, and effect of SCY-078, a novel glucan synthesis inhibitor, on growth morphology and biofilm formation. Antimicrob Agents Chemother. 2017;61(5):e02396-16.

67. Navalkele BD, Revankar S, Chandrasekar P. Candida auris: a worrisome, globally emerging pathogen. Expert Rev Anti Infect Ther. 2017;15(9):819-827.

68. Chandra J, Kuhn DM, Mukherjee PK, Hoyer LL, McCormick T, Ghannoum MA. Biofilm formation by the fungal pathogen Candida albicans: development, architecture, and drug resistance. J Bacteriol. 2001;183(18):5385-5394.
69. Chandra J, McCormick TS, Imamura Y, Mukherjee PK, Ghannoum MA. Interaction of Candida albicans with adherent human peripheral blood mononuclear cells increases $C$. albicans biofilm formation and results in differential expression of pro- and anti-inflammatory cytokines. Infect Immun. 2007;75(5):2612-2620.

70. Kim HS, Choi EH, Khan J, et al. Expression of genes encoding innate host defense molecules in normal human monocytes in response to Candida albicans. Infect Immun. 2005;73(6):3714-3724.

71. Pfaller MA, Diekema DJ. Epidemiology of invasive candidiasis: a persistent public health problem. Clin Microbiol Rev. 2007;20(1):133-163.

72. Kumar A, Roberts D, Wood KE, et al. Duration of hypotension before initiation of effective antimicrobial therapy is the critical determinant of survival in human septic shock. Crit Care Med. 2006;34(6): 1589-1596.

73. Golan Y, Wolf MP, Pauker SG, Wong JB, Hadley S. Empirical antiCandida therapy among selected patients in the intensive care unit: a cost-effectiveness analysis. Ann Intern Med. 2005;143(12):857-869.

74. Ostrosky-Zeichner L, Kullberg BJ, Bow EJ, et al. Early treatment of candidemia in adults: a review. Med Mycol. 2011;49(2):113-120.

75. Posch W, Heimdörfer D, Wilflingseder D, Lass-Flörl C. Invasive candidiasis: future directions in non-culture based diagnosis. Expert Rev Anti Infect Ther. 2017;15(9):829-838.

76. Kriengkauykiat J, Ito JI, Dadwal SS. Epidemiology and treatment approaches in management of invasive fungal infections. Clin Epidemiol. 2011;3:175-191.

77. Clancy CJ, Nguyen MH. Finding the "Missing 50\%" of invasive candidiasis: how nonculture diagnostics will improve understanding of disease spectrum and transform patient care. Clin Infect Dis. 2013;56(9):1284-1292.

78. Nguyen MH, Wissel MC, Shields RK, et al. Performance of Candida real-time polymerase chain reaction, $\beta$-D-glucan assay, and blood cultures in the diagnosis of invasive candidiasis. Clin Infect Dis. 2012;54(9):1240-1248.

79. Yamanouchi K, Takatsuki M, Hidaka M, Soyama A, Kanematsu T, Eguchi S. Significance of serum $\beta$-d-glucan levels in recipients of living donor liver transplantation. J Hepatobiliary Pancreat Sci. 2011;18(3): 432-435.

80. Avni T, Leibovici L, Paul M. PCR Diagnosis of invasive candidiasis: systematic review and meta-analysis. J Clin Microbiol. 2011;49(2):665-670.

81. Colombo AL, de Almeida Junior JN, Slavin MA, Chen SC, Sorrell TC. Candida and invasive mould diseases in non-neutropenic critically ill patients and patients with haematological cancer. Lancet Infect Dis. 2017;17(11):e344-e356.

82. Snydman DR. Shifting patterns in the epidemiology of nosocomial Candida infections. Chest. 2003;123(5 Suppl):500S-503S.

83. Hall AM, Poole LA, Renton B, et al. Prediction of invasive candidal infection in critically ill patients with severe acute pancreatitis. Crit Care. 2013;17(2):R49.

84. Ahmed A, Baronia AK, Azim A, et al. External validation of risk prediction scores for invasive candidiasis in a medical/surgical intensive care unit: an observational study. Indian J Crit Care Med. 2017;21(8):514-520.

85. Arendrup MC, Perlin DS. Echinocandin resistance: an emerging clinical problem? Curr Opin Infect Dis. 2014;27(6):484-492.

86. Perlin DS. Echinocandin resistance, susceptibility testing and prophylaxis: implications for patient management. Drugs. 2014;74(14):1573-1585.

87. Shields RK, Nguyen MH, Press EG, et al. The presence of an FKS mutation rather than MIC is an independent risk factor for failure of echinocandin therapy among patients with invasive candidiasis due to Candida glabrata. Antimicrob Agents Chemother. 2012;56(9):4862-4869.

88. Tagliaferri E, Menichetti F. Treatment of invasive candidiasis: between guidelines and daily clinical practice. Expert Rev Anti Infect Ther. 2015;13(6):685-689.

89. Yang ZT, Wu L, Liu XY, et al. Epidemiology, species distribution and outcome of nosocomial Candida spp. bloodstream infection in Shanghai. BMC Infect Dis. 2014;14:241-241. 
90. Chapman B, Slavin M, Marriott D, et al. Changing epidemiology of candidaemia in Australia. J Antimicrob Chemother. 2017;72(4):1270.

91. Kucharikova S, Gerits E, De Brucker K, et al. Covalent immobilization of antimicrobial agents on titanium prevents Staphylococcus aureus and Candida albicans colonization and biofilm formation. JAntimicrob Chemother. 2016;71(4):936-945.

92. Tissot F, Agrawal S, Pagano L, et al. ECIL-6 guidelines for the treatment of invasive candidiasis, aspergillosis and mucormycosis in leukemia and hematopoietic stem cell transplant patients. Haematologica 2017;102(3):433-444.

93. Scudeller L, Viscoli C, Menichetti F, et al. An Italian consensus for invasive candidiasis management (ITALIC). Infection. 2014;42(2):263-279.

94. Lucey MR, Terrault N, Ojo L, et al. Long-term management of the successful adult liver transplant: 2012 practice guideline by the American Association for the Study of Liver Diseases and the American Society of Transplantation. Liver Transpl. 2013;19(1):3-26.

95. Kohno S, Izumikawa K, Yoshida M, et al. A double-blind comparative study of the safety and efficacy of caspofungin versus micafungin in the treatment of candidiasis and aspergillosis. Eur J Clin Microbiol Infect Dis. 2013;32(3):387-397.

96. Arendrup MC, Perlin DS, Jensen RH, Howard SJ, Goodwin J, Hope W. Differential in vivo activities of anidulafungin, caspofungin, and micafungin against Candida glabrata isolates with and without FKS resistance mutations. Antimicrob Agents Chemother. 2012;56(5):2435-2442.

97. Eschenauer GA, Carver PL, Lin SW, et al. Fluconazole versus an echinocandin for Candida glabrata fungaemia: a retrospective cohort study. J Antimicrob Chemother. 2013;68(4):922-926.

98. Jung DS, Tverdek FP, Jiang Y, Kontoyiannis DP. Switching to anidulafungin from caspofungin in cancer patients in the setting of liver dysfunction is associated with improvement of liver function tests. $J$ Antimicrob Chemother. 2015;70(11):3100-3106.

99. Patil A, Majumdar S. Echinocandins in antifungal pharmacotherapy. J Pharm Pharmacol. 2017;69(12):1635-1660.

100. Kofla G, Ruhnke M. Pharmacology and metabolism of anidulafungin, caspofungin and micafungin in the treatment of invasive candidosis review of the literature. Eur J Med Res. 2011;16(4):159-166.

101. Denning DW. Echinocandin antifungal drugs. Lancet. 2003; 362(9390):1142-1151.

102. Gil-Alonso S, Jauregizar N, Canton E, Eraso E, Quindos G. Comparison of the in vitro activity of echinocandins against Candida albicans, Candida dubliniensis, and Candida africana by time-kill curves. Diagn Microbiol Infect Dis. 2015;82(1):57-61.

103. Lepak A, Castanheira M, Diekema D, Pfaller M, Andes D. Optimizing echinocandin dosing and susceptibility breakpoint determination via in vivo pharmacodynamic evaluation against Candida glabrata with and without fks mutations. Antimicrob Agents Chemother. 2012;56(11): 5875-5882.

104. Ernst EJ, Roling EE, Petzold CR, Keele DJ, Klepser ME. In vitro activity of micafungin (FK-463) against Candida spp.: microdilution, time-kill, and postantifungal-effect studies. Antimicrob Agents Chemoth. 2002;46(12):3846-3853.

105. Ernst EJ, Klepser ME, Pfaller MA. Postantifungal effects of echinocandin, azole, and polyene antifungal agents against Candida albicans and Cryptococcus neoformans. Antimicrob Agents Chemother 2000;44(4):1108-1111.

106. Bellmann R, Smuszkiewicz P. Pharmacokinetics of antifungal drugs: practical implications for optimized treatment of patients. Infection 2017;45(6):737-779.

107. Olson JC, Wendon JA, Kramer DJ, et al. Intensive care of the patient with cirrhosis. Hepatology. 2011;54(5):1864-1872.

108. Zauner CA, Apsner RC, Kranz A, et al. Outcome prediction for patients with cirrhosis of the liver in a medical ICU: a comparison of the APACHE scores and liver-specific scoring systems. Intensive Care Med. 1996;22(6):559-563.

109. Cholongitas E, Senzolo M, Patch D, et al. Risk factors, sequential organ failure assessment and model for end-stage liver disease scores for predicting short term mortality in cirrhotic patients admitted to intensive care unit. Aliment Pharmacol Ther. 2006;23(7):883-893.
110. Bittencourt PL, Terra C, Parise ER, et al. Intensive care management of patients with liver disease: proceedings of a single-topic conference sponsored by the Brazilian Society of Hepatology. Arq Gastroenterol. 2015;52(Suppl 1):55-72.

111. Ahmed A, Azim A, Baronia A, Marak KR, Gurjar M. Risk prediction for invasive candidiasis. Indian J Crit Care Med. 2014;18(10): 682-688.

112. Mistry GC, Migoya E, Deutsch PJ, et al. Single- and multiple-dose administration of caspofungin in patients with hepatic insufficiency: implications for safety and dosing recommendations. J Clin Pharmacol. 2007;47(8):951-961.

113. Martial LC, Brüggemann RJ, Schouten JA, et al. Dose reduction of caspofungin in intensive care unit patients with Child Pugh B will result in suboptimal exposure. Clin Pharmacokinet. 2016;55(6):723-733.

114. Nguyen TH, Hoppe-Tichy T, Geiss HK, et al. Factors influencing caspofungin plasma concentrations in patients of a surgical intensive care unit. J Antimicrob Chemother. 2007;60(1):100-106.

115. Weiler S, Seger C, Pfisterer H, et al. Pharmacokinetics of caspofungin in critically ill patients on continuous renal replacement therapy. Antimicrob Agents Chemother. 2013;57(8):4053-4057.

116. Muilwijk EW, Schouten JA, van Leeuwen HJ, et al. Pharmacokinetics of caspofungin in ICU patients. J Antimicrob Chemother. 2014;69(12):3294-3299.

117. Du QQ, Wang ZJ, He L, Jiang XH, Wang L. PXR polymorphisms and their impact on pharmacokinetics/pharmacodynamics of repaglinide in healthy Chinese volunteers. Eur J Clin Pharmacol. 2013;69(11):1917-1925.

118. Stone JA, Migoya EM, Hickey L, et al. Potential for interactions between caspofungin and nelfinavir or rifampin. Antimicrob Agents Chemother. 2004;48(11):4306-4314.

119. Lang CC, Jamal SK, Mohamed Z, Mustafa MR, Mustafa AM, Lee TC. Evidence of an interaction between nifedipine and nafcillin in humans. Br J Clin Pharmacol. 2003;55(6):588-590.

120. Yasuda K, Ranade A, Venkataramanan R, et al. A comprehensive in vitro and in silico analysis of antibiotics that activate pregnane $\mathrm{X}$ receptor and induce CYP3A4 in liver and intestine. Drug Metab Dispos. 2008;36(8):1689-1697.

121. Eschenauer G, Depestel DD, Carver PL. Comparison of echinocandin antifungals. Ther Clin Risk Manag. 2007;3(1):71-97.

122. Sable CA, Nguyen BY, Chodakewitz JA, DiNubile MJ. Safety and tolerability of caspofungin acetate in the treatment of fungal infections. Transpl Infect Dis. 2002;4(1):25-30.

123. Ullmann AJ. Review of the safety, tolerability, and drug interactions of the new antifungal agents caspofungin and voriconazole. Curr Med Res Opin. 2003;19(4):263-271.

124. Undre N, Pretorius B, Stevenson P. Pharmacokinetics of micafungin in subjects with severe hepatic dysfunction. Eur J Drug Metab Pharmacokinet. 2015;40(3):285-293.

125. Hebert MF, Smith HE, Marbury TC, et al. Pharmacokinetics of micafungin in healthy volunteers, volunteers with moderate liver disease, and volunteers with renal dysfunction. J Clin Pharmacol. 2005;45(10):1145-1152.

126. Jullien V, Azoulay E, Schwebel C, et al. Population pharmacokinetics of micafungin in ICU patients with sepsis and mechanical ventilation. J Antimicrob Chemother. 2017;72(1):181-189.

127. Lempers VJ, Schouten JA, Hunfeld NG, et al. Altered micafungin pharmacokinetics in intensive care unit patients. Antimicrob Agents Chemother. 2015;59(8):4403-4409.

128. Boonstra JM, van der Elst KC, Veringa A, et al. Pharmacokinetic properties of micafungin in critically ill patients diagnosed with invasive candidiasis. Antimicrob Agents Chemother. 2017;61(12):e01398-e013117.

129. Hebert MF, Townsend RW, Austin S, et al. Concomitant Cyclosporine and Micafungin Pharmacokinetics in Healthy Volunteers. J Clin Pharmacol. 2005;45(8):954-960.

130. Gubbins PO, Amsden JR. Drug-drug interactions of antifungal agents and implications for patient care. Expert Opin Pharmacother. 2005;6(13):2231-2243. 
131. European Medicines Agency. Mycamine. EPAR - Product Information 2011. Available from: http://www.ema.europa.eu/docs/en_GB/ document_library/EPAR_-_Public_assessment_report/human/000734/ WC500031079.pdf. Accessed January 29, 2018.

132. Mycomycin (micafungin) [prescribing information]. Singapore: Health Services Authority SAPT, Co., Ltd; 2016. Available from: https:// eservice.hsa.gov.sg/prism/common/enquirepublic/SearchDRBProduct. do?action=getProductDetails. Accessed January 29, 2018.

133. Dowell JA, Stogniew M, Krause D, Damle B. Anidulafungin does not require dosage adjustment in subjects with varying degrees of hepatic or renal impairment. J Clin Pharmacol. 2007;47(4):461-470.

134. Brüggemann RJ, Middel-Baars V, de Lange DW, et al. Pharmacokinetics of anidulafungin in critically ill intensive care unit patients with suspected or proven invasive fungal infections. Antimicrob Agents Chemother. 2017;61(2). pii: e01894-e018116.

135. Liu P, Ruhnke M, Meersseman W, Paiva JA, Kantecki M, Damle B. Pharmacokinetics of anidulafungin in critically ill patients with candidemia/invasive candidiasis. Antimicrob Agents Chemother. 2013;57(4):1672-1676.

136. van Wanrooy MJP, Proost JH, Rodgers MGG, et al. Limited-sampling strategies for anidulafungin in critically ill patients. Antimicrob Agents Chemother. 2015;59(2):1177-1181.

137. Muilwijk EW, Lempers VJ, Burger DM, et al. Impact of special patient populations on the pharmacokinetics of echinocandins. Expert Rev Anti Infect Ther. 2015;13(6):799-815.

138. Dowell JA, Stogniew M, Krause D, Henkel T, Weston IE. Assessment of the safety and pharmacokinetics of anidulafungin when administered with cyclosporine. J Clin Pharmacol. 2005;45(2):227-233.

139. Vergis N, Atkinson SR, Knapp S, et al. In patients with severe alcoholic hepatitis, prednisolone increases susceptibility to infection and infection-related mortality, and is associated with high circulating levels of bacterial DNA. Gastroenterology. 2017;152(5):1068-1077.e1064.

140. Zicker M, Colombo AL, Ferraz-Neto BH, Camargo LF. Epidemiology of fungal infections in liver transplant recipients: a six-year study of a large Brazilian liver transplantation centre. Mem Inst Oswaldo Cruz. 2011;106(3):339-345.

141. Sganga G, Bianco G, Frongillo F, Lirosi MC, Nure E, Agnes S. Fungal infections after liver transplantation: incidence and outcome. Transplant Proc. 2014;46(7):2314-2318.

142. Donato L, González T, Canales M, Legarraga P, García P, Rabagliati R. Evaluación del rendimiento de 1,3- $\beta$-d-glucano como apoyo diagnóstico de infecciones invasoras por Candida spp. en pacientes críticos adultos [The 1,3- $\beta$-d-glucan in critical adult patients as diagnostic tool for invasive Candida spp. infection, performance evaluation]. Rev Chilena Infectol. 2017;34(4):340-346. Spanish [with English abstract].

143. Wheat LJ. Approach to the diagnosis of invasive aspergillosis and candidiasis. Clin Chest Med. 2009;30(2):367-377, viii.

144. Akamatsu N, Sugawara Y, Kaneko J, Tamura S, Makuuchi M. Preemptive treatment of fungal infection based on plasma $(1 \rightarrow 3)$ beta-D-glucan levels after liver transplantation. Infection. 2007;35(5):346-351.

145. Gupta P, Ahmad A, Khare V, et al. Comparative evaluation of panfungal real-time PCR, galactomannan and (1-3)- $\beta$-D-glucan assay for invasive fungal infection in paediatric cancer patients. Mycoses. 2017;60(4):234-240.

146. Singh N, Winston DJ, Limaye AP, et al. Performance characteristics of galactomannan and $\beta$-d-glucan in high-risk liver transplant recipients. Transplantation. 2015;99(12):2543-2550.

147. Demiraslan H, Atalay MA, Eren E, et al. Assessing the risk of false positive serum galactomannan among patients receiving piperacillin/ tazobactam for febrile neutropenia. Med Mycol. 2017;55(5):535-540.

148. De Pauw B, Walsh TJ, Donnelly JP, et al. Revised definitions of invasive fungal disease from the European Organization for Research and Treatment of Cancer/Invasive Fungal Infections Cooperative Group and the National Institute of Allergy and Infectious Diseases Mycoses Study Group (EORTC/MSG) Consensus Group. Clin Infect Dis. 2008;46(12):1813-1821.
149. Thaler M, Pastakia B, Shawker TH, O’Leary T, Pizzo PA. Hepatic candidiasis in cancer patients: the evolving picture of the syndrome. Ann Intern Med. 1988;108(1):88-100.

150. Pfeiffer CD, Samsa GP, Schell WA, Reller LB, Perfect JR, Alexander BD. Quantitation of Candida CFU in initial positive blood cultures. $J$ Clin Microbiol. 2011;49(8):2879-2883.

151. Majeed A, Ullah W, Zahid U, Al Mohajer M. Persistent spontaneous fungal peritonitis secondary to Candida albicans in a patient with alcoholic cirrhosis and review of the literature. BMJ Case Rep. 2016;2016:bcr2016216979.

152. Dupont H, Paugam-Burtz C, Muller-Serieys C, et al. Predictive factors of mortality due to polymicrobial peritonitis with Candida isolation in peritoneal fluid in critically ill patients. Arch Surg. 2002;137(12): 1341-1346.

153. Montravers P, Dupont $\mathrm{H}$, Gauzit R, et al. Candida as a risk factor for mortality in peritonitis. Crit Care Med. 2006;34(3):646-652.

154. Chakravarty-Vartak US, Taklikar SM, Baradkar VP, Vartak S, Bhatt N. Peritonitis due to Candida albicans in a patient with chronic hepatitis C infection. Saudi J Gastroenterol. 2008;14(3):147.

155. Blot SI, Vandewoude KH, De Waele JJ. Candida peritonitis. Curr Opin Crit Care. 2007;13(2):195-199.

156. Rex JH. Candida in the peritoneum: passenger or pathogen? Crit Care Med. 2006;34(3):902-903.

157. Stone EA, Fung HB, Kirschenbaum HL. Caspofungin: an echinocandin antifungal agent. Clin Therapeut. 2002;24(3):351-377.

158. Smith RP, Baltch A, Bopp LH, Ritz WJ, Michelsen PP. Post-antifungal effects and time-kill studies of anidulafungin, caspofungin, and micafungin against Candida glabrata and Candida parapsilosis. Diagn Microbiol Infect Dis. 2011;71(2):131-138.

159. Aguilar G, Azanza JR, Carbonell JA, et al. Anidulafungin dosing in critically ill patients with continuous venovenous haemodiafiltration. J Antimicrob Chemother. 2014;69(6):1620-1623.

160. Aguilar G, Azanza JR, Sádaba B, et al. Pharmacokinetics of anidulafungin during albumin dialysis. Crit Care. 2014;18(2):422.

161. Kolbinger P, Gruber M, Roth G, Graf BM, Ittner KP. Filter adsorption of anidulafungin to a polysulfone-based hemofilter during CVVHD in vitro. Artif Organs. 2018:42(2):200-207.

162. Leitner JM, Meyer B, Fuhrmann V, et al. Multiple-dose pharmacokinetics of anidulafungin during continuous venovenous haemofiltration. $J$ Antimicrob Chemother. 2011;66(4):880-884.

163. Roger C, Wallis SC, Muller L, et al. Caspofungin population pharmacokinetics in critically ill patients undergoing continuous venovenous haemofiltration or haemodiafiltration. Clin Pharmacokinet. 2017;56(9):1057-1068.

164. Pérez-Pitarch A, Ferriols-Lisart R, Aguilar G, Ezquer-Garín C, Belda FJ, Guglieri-López B. Dosing of caspofungin based on a pharmacokinetic/pharmacodynamic index for the treatment of invasive fungal infections in critically ill patients on continuous venovenous haemodiafiltration. Int J Antimicrob Agents. 2018;51(1):115-121.

165. Johnson MD, Perfect JR. Caspofungin: first approved agent in a new class of antifungals. Expert Opin Pharmacother. 2003;4(5): 807-823.

166. Sandhu P, Lee W, Xu X, et al. Hepatic uptake of the novel antifungal agent caspofungin. Drug Metab Dispos. 2005;33(5):676-682.

167. Lexicomp Online [Subscription Only]. Facts and Comparisons. 2018; Available from: https://online.lexi.com/lco/action/home. Accessed January 25, 2017.

168. European Medicines Agency. Assessment Report for Mycamine. Available from: http://www.ema.europa.eu/docs/en_GB/document_library/ EPAR_-_Public_assessment_report/human/000734/WC500031079. pdf. Accessed January 29, 2018.

169. Spriet I, Meyfroidt G, Maleux G, Verslype C, Willems L. The impact of a transjugular intrahepatic portosystemic shunt on the pharmacokinetics of caspofungin in a critically ill patient. Pharmacology. 2012;90(5-6):247-250. 
Infection and Drug Resistance is an international, peer-reviewed openaccess journal that focuses on the optimal treatment of infection (bacterial, fungal and viral) and the development and institution of preventive strategies to minimize the development and spread of resistance. The journal is specifically concerned with the epidemiology of antibiotic
Dovepress

resistance and the mechanisms of resistance development and diffusion in both hospitals and the community. The manuscript management system is completely online and includes a very quick and fair peerreview system, which is all easy to use. Visit http://www.dovepress.com/ testimonials.php to read real quotes from published authors.

Submit your manuscript here: https://www.dovepress.com/infection-and-drug-resistance-journal 